\title{
The Application of Learning to Reading Without Spell Method in Increase the Reading Skill in The First Grade Elementary School Students
}

\section{Fitria Dwi Kurniawati}

SDN 1 Bugel

wiwikjepara0@gmail.com

\section{Article History}

accepted 01/11/2020

\begin{abstract}
This research have purpose to increase the reading the skill in the firsth grade elementary school students. This research is a classroom action research conducted in three cycles, each cycle includes the planning, implementation, observation and reflection. The subjects were students first grade elementary school. Data source of this study are were students first grade elementary school, first grade elementary school teacher, and observers. The data analysis technique consists of three components, that is data reduction, data presentation, and conclusion or verification. The results show that the application of learning to reading without spell metod can be improve the reading skill first grade student elementary school.
\end{abstract}

Keywords: learning to reading without spell, the skill, metod.

\begin{abstract}
Abstrak
Penelitian ini bertujuan untuk meningkatkan keterampilan membaca siswa kelas I SDN 1 Bugel dengan metode Belajar Membaca Tanpa Mengeja. Penelitian ini adalah penelitian tindakan kelas yang dilaksanakan dalam tiga siklus, masing-masing siklus mencakup tahap perencanaan, pelaksanaan, observasi dan refleksi. Subjek penelitian ini adalah siswa kelas I SDN 1 Bugel. Sumber data penelitian ini adalah siswa kelas I SDN 1 Bugel, guru kelas I SDN 1 Bugel, dan observer. Teknik analisis data terdiri dari tiga komponen analisis yaitu reduksi data, penyajian data, dan penarikan kesimpulan atau verifikasi. Hasilnya menunjukkan bahwa penerapan metode Belajar Membaca Tanpa Mengeja dapat meningkatkan keterampilan membaca siswa kelas I SDN 1 Bugel.
\end{abstract}

Kata kunci: belajar membaca tanpa mengeja, keterampilan, metode.

\author{
Social, Humanities, and Education Studies (SHEs): \\ Conference Series \\ https://jurnal.uns.ac.id/shes
}

p-ISSN 2620-9284

e-ISSN 2620-9292 


\section{PENDAHULUAN}

Bahasa Indonesia sebagai bahasa pengantar pendidikan Negara Indonesia di semua jenis dan jenjang sekolah mulai dari taman kanak-kanak sampai dengan perguruan ting-gi. Mata Pelajaran Bahasa Indonesia memegang peranan penting dalam pembaruan dan peningkatan mutu pendidikan. Oleh karena itu, Mata Pelajaran Bahasa Indonesia merupa-kan mata pelajaran yang penting bagi anak usia sekolah dasar karena melalui mata pelajaran ini siswa diajarkan keterampilan berbahasa (mendengar, berbicara, membaca, dan menulis).

Seseorang akan memperoleh berbagai pengetahuan baru yang mampu meningkatkan wawasannya sehingga mereka lebih mampu menjawab tantangan hidup kedepan yang semakin kompleks. Masyarakat yang kompleks setiap jam bergantung pada kapasitas membaca dan menulis warganya untuk membuat per-timbangan rumit dan bertindak ber-dasarkan informasi yang luas (Ahuja, P dan Ahuja, G.C. 2010: 5).

Namun banyak siswa kelas I yang belum menguasai keterampilan membaca, padahal keterampilan ini menjadi dasar bagi keterampilan lain, sehingga siswa mengalami kesulitan menguasai materi pelajaran yang banyak diperoleh melalui membaca.

Pembelajaran Bahasa Indonesia di SDN 1 Bugel masih menggunakan metode pembelajaran konvensional didominasi oleh guru. Dalam mengantarkan anak menguasai keterampilan membaca guru hanya menggunakan metode mengeja, anak harus duduk, diam, dan ber-konsentrasi, dan harus menghafal 26 huruf.

Hal tersebut membuat siswa kurang termotivasi untuk aktif dalam kegiatan pembelajaran. Siswa akan merasa bosan dan kurang berminat dalam proses pembelajaran karena dalam metode pembelajaran kon-vensional pembelajaran hanya ter-pusat pada guru, siswa kurang leluasa untuk aktif dan berkreasi dalam pembelajaran yang akhirnya bisa membuat konsentrasi siswa kurang terfokus pada pembelajaran. Hal tersebut membuat minat belajar siswa dalam kegiatan pembelajaran rendah.

Salah satu metode pembelajaran yang tepat adalah metode Belajar Membaca Tanpa Mengeja (BMTM). metode BMTM merupakan suatu cara atau teknik mengajarkan siswa dalam menguasai ketrampilan membaca dengan tidak mengeja (Noviana, 2008). Metode BMTM merupakan suatu metode pembelajaran yang dirasa tepat dan efektif dalam upaya peningkatkan keterampilan membaca siswa kelas I SDN 1 Bugel.

Pada penerapan metode Belajar Membaca Tanpa Mengeja, siswa tidak harus duduk diam, dan ber-konsentrasi, melainkan siswa aktif dalam pembelajaran melalui kegiatan bermain, menggambar, mewarnai atau bermain peran. Permainan atau kegiatan dapat disusun guru dalam bentuk kegiatan berkelompok kecil ataupun secara klasikal. Ketika ber-main siswa menemukan kebebasan dirinya untuk bekspresi dan menemu-kan kesenangan mereka (Noviana, 2009).

Penerapan metode Belajar Membaca Tanpa Mengeja diharapkan dapat meningkatkan ketrampilan membaca. Melalui metode BMTM ini siswa akan lebih berminat dan ter-motivasi, karena dengan permainan atau kegiatan yang menarik dan menyenangkan.

Siswa akan lebih leluasa untuk aktif dan berkreasi dalam pem-belajaran karena pada proses pem-belajaran tidak hanya berpusat pada guru saja. Dalam bermain atau berkegiatan siswa benar-benar mem-perlihatkan keseriusan, ketertarikan dan kesungguhan mereka dalam mengikuti pembelajaran yang di-sajikan oleh guru. Dengan demikian, keberhasilan pembelajaran Bahasa Indonesia khususnya dalam me-ningkatkan ketrampilan membaca da-pat tercapai sesuai dengan tujuan pembelajaran. 
SHEs: Conference Series 3 (3) (2020) $250-255$

Berdasarkan kenyataan tersebut di atas maka penulis tertarik untuk mengadakan penelitian tentang penerapan metode Belajar Membaca Tanpa Mengeja (BMTM) dalam pe-ningkatan keterampilan membaca pada siswa kelas I SD Negeri 1 Bugel tahun ajaran 2020/2021.

Rumusan masalah yang muncul yaitu apakah penerapan metode Belajar Membaca Tanpa Mengeja (BMTM) dapat meningkatan ke-terampilan membaca siswa kelas I SDN 1 Bugel Tahun Ajaran 2020/2021?

Tujuan penelitian ini yaitu untuk meningkatkan ketrampilan membaca siswa kelas I SD Negeri 1 Bugel Tahun Ajaran 2020/2021 dengan menerapkan metode Belajar Membaca Tanpa Mengeja (BMTM).

\section{METODE}

Penelitian dilaksanakan di SDN 1 Bugel Kecamatan Kedung Kabupaten Jepara. Jumlah subjek penelitian sebanyak 17 siswa yang terdiri atas 6 siswa laki-laki dan 11 siswa perempuan. Waktu penelitian mulai bulan Oktober 2020 sampai bulan November 2020.

Sumber data yang digunakan dalam penelitian ini diperoleh dari berbagai sumber yaitu guru (peneliti), siswa, teman sejawat, dan kepala sekolah. Data yang diperoleh dari subjek penelitian yaitu siswa kelas I SD Negeri 1 Bugel tahun ajaran 2020/2021 mencakup proses belajar dan hasil belajar siswa khususnya dalam pembelajaran Bahasa Indo-nesia pada aspek keterampilan mem-baca.

Data tersebut juga didukung data yang berasal dari guru atau teman sejawat, melalui observasi dan kegiatan pembelajaran. Alat pengumpulan data dalam penelitian ini antara lain lembar tes hasil belajar, lembar observasi, lembar angket, dan pe-doman wawancara. Pada penelitian ini alat pengumpulan data digunakan untuk mengukur proses pelaksanaan penerapan metode Belajar Membaca Tanpa Mengeja (BMTM) dan ke-terampilan membaca siswa.

Teknik analisis data yang dipergunakan dalam penelitian ini adalah teknik deskriptif dengan didukung data kualitatif dan kuantitatif. Prosedur analisis data yang dilakukan dalam penelitian ini yaitu meliputi reduksi data, penyajian data dan penarikan kesimpulan.

Indikator kinerja penelitian pada penelitian ini adalah tercapainya nilai rata-rata kelas dapat mencapai kriteria ketuntasan minimum (KKM) yang telah ditetapkan yaitu 70 baik pada tes ketrampilan membaca maupun pada tes kognitif membaca, serta jumlah siswa yang mendapat nilai tuntas atau mencapai KKM yang telah ditetapkan mencapai $85 \%$ dari jumlah keseluruhan siswa.

Metode penelitian ini menggunakan model penelitian tindakan kelas yang dikembangkan oleh Kem-mis dan Mc. Taggart yaitu menggunakan sistem spiral refleksi diri yang dimulai dengan perencanaan, tindakan, observasi, refleksi, dan perencanaan kembali merupakan dasar untuk suatu ancang-ancang pemecahan permasalahan (Kasbolah, 2001). Pelaksanaan tindakan ini dilakukan dalam tiga siklus, yang masing-masing siklus melalui dua kali pertemuan.

\section{HASIL DAN PEMBAHASAN}

Pada tahap perencanaan, peneliti menyusun skenario pembelajaran dan RPP dengan menggunakan metode Belajar Membaca Tanpa Mengeja (BMTM). Peneliti juga menyiapkan instrumen yang dibutuhkan seperti lembar observasi, kuesioner, dan lembar evaluasi.

Peneliti melakukan pretes dengan nilai rata-rata 50.00 dengan nilai terendah 20 dan nilai tertinggi 80 pada tes kognitif membaca. Sementara itu, pada tes psikomotor 
membaca pretes dengan nilai rata-rata 54.71 dengan nilai terendah 25 dan nilai tertinggi 80 . KKM pada pe-nelitian ini adalah 70 sehingga siswa yang dinyatakan belum tuntas ada 14 untuk tes kognitif membaca dan 15 siswa untuk tes psikomotor membaca. Berdasarkan data tersebut perlu diadakan tindakan untuk memperbaiki hasil belajar Bahasa Indonesia pada aspek keterampilan membaca pada siswa kelas I SDN 1 Bugel tahun ajaran 2020/2021.

Berdasarkan analisis yang telah dilakukan pada tiap pertemuan, hasil akhir siklus I-III adalah sebagai berikut:

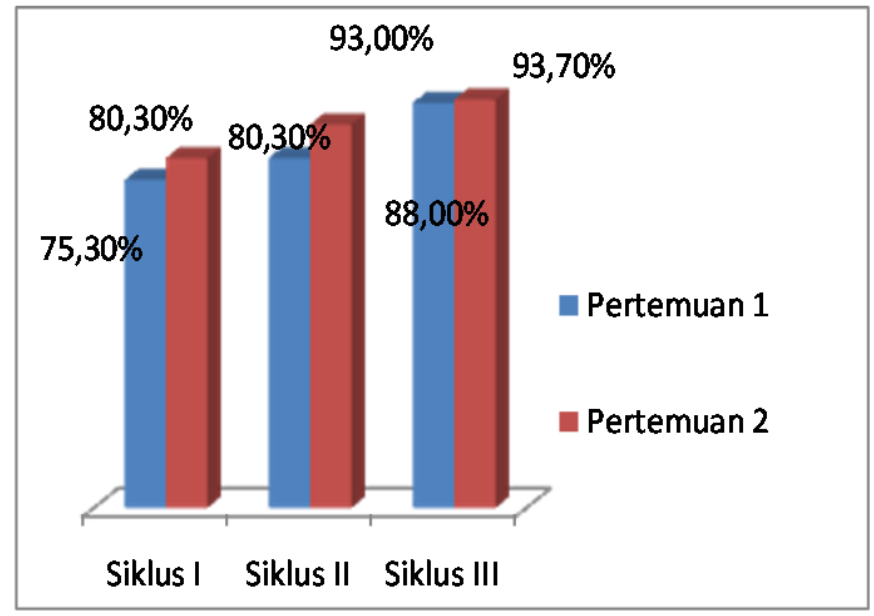

Gambar 1. Hasil observasi pada Guru

Berdasarkan gambar 1, kegiatan guru dalam pembelajaran mengalami peningkatan di tiap siklus. Pada siklus I mengalami peningkatan dari $75.30 \%$ pada pertemuan 1 menjadi $80.30 \%$ pada pertemuan 2. Pada siklus II mengalami peningkatan yaitu dari semula $80.30 \%$ pada pertemuan 1 menjadi $93.00 \%$ pada pertemuan 2. Pada siklus III kembali mengalami peningkatan yaitu dari $88,00 \%$ pada pertemuan 1 menjadi $93.70 \%$ pada pertemuan 2 . Hasil tersebut menunjukkan bahwa proses pembelajaran sudah berjalan dengan baik dan sudah mencapai indikator kinerja yang ditentukan yaitu $85 \%$.

Adapun hasil observasi terhadap siswa dalam mengikuti proses pembelajaran menggunakan me-tode Belajar Membaca Tanpa Mengeja dari siklus I-III dapat dilihat pada gambar berikut ini.

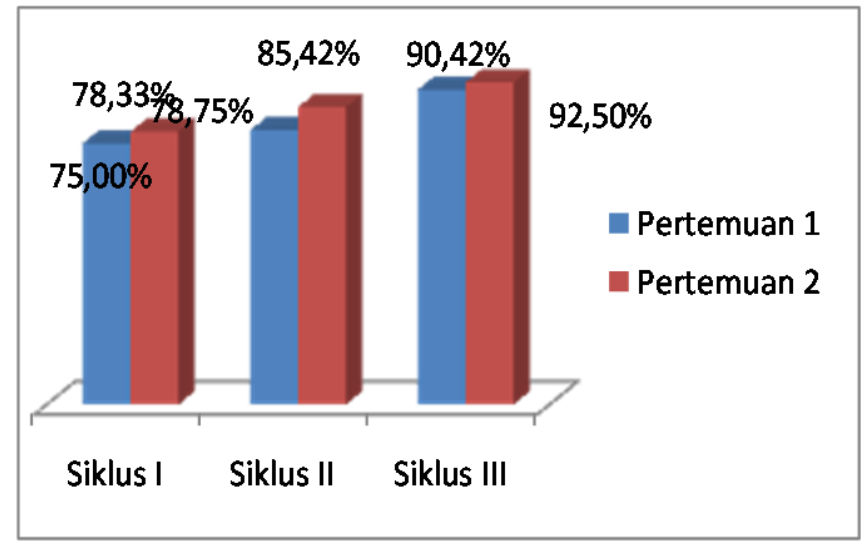

Gambar 2. Hasil observasi pada siswa 
Pada gambar 2 proses belajar siswa dalam mengikuti proses pembelajaran menggunakan metode Belajar Membaca Tanpa Mengeja mengalami peningkatan dalam setiap siklus. Pada siklus I terjadi peningkatan yang yaitu dari $75,00 \%$ pada pertemuan 1 menjadi $78.33 \%$ pada pertemuan 2. Pada siklus II hasil observasi menunjukkan bahwa pada pertemuan 1 dan pertemuan 2 sama yakni 78,75\%. Namun pada siklus III kembali meningkat yaitu dari $90,42 \%$ pada pertemuan 1 menjadi $92.50 \%$ pada pertemuan 2. Hal tersebut menunjukkan bahwa proses pembelajaran sudah berjalan dengan baik dan sudah mencapai indikator kinerja yang ditentukan yakni $85 \%$.

Berdasarkan analisis hasil belajar siswa pada siklus I-III rerata hasil belajar siswa dapat dilihat pada gambar di bawah ini.

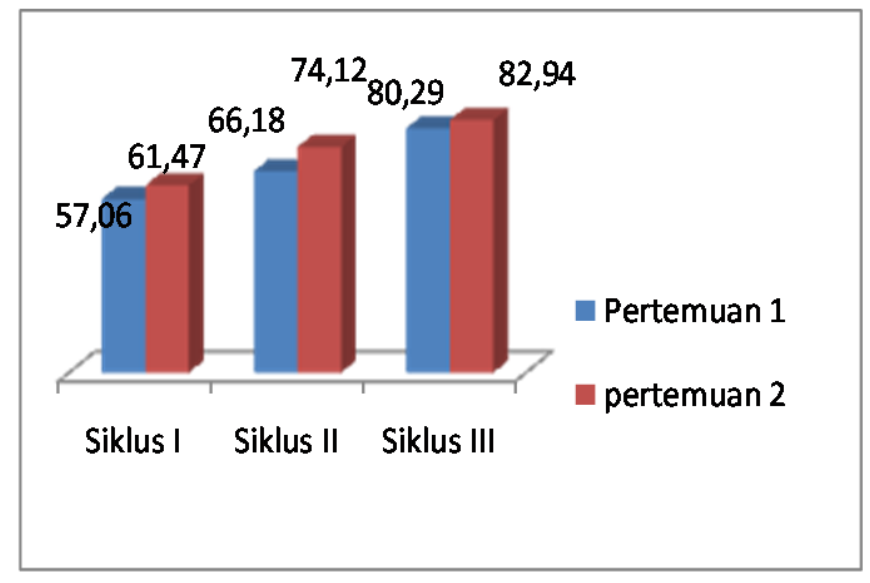

Gambar 3. Hasil belajar siswa

Berdasarkan gambar 3 dinyatakan bahwa rerata hasil belajar siswa siswa pada siklus I mengalami peningkatan dari 57.06 pada pertemuan 1 menjadi 61.47 pada pertemuan 2. Sedangkan pada pertemuan II meningkat dari 66.18 menjadi 75.12. Pada siklus III kembali meningkat dari 80.29 pada pertemuan 1 menjadi 82.94 pada pertemuan 2. Data hasil belajar tersebut menunjukkan bahwa penggunaan metode Belajar Membaca Tanpa Mengeja (BMTM) meningkatkan hasil belajar siswa pada aspek keterampilan membaca dan hasil belajar tersebut sudah mencapai KKM yang ditentukan yaitu 70 .

Keberhasilan pembelajaran Bahasa Indonesia pada aspek keterampilan membaca siswa kelas I SD Negeri 1 Bugel ditandai dengan adanya peningkatan dan perubahan pada setiap siklus, menurut Asrori (2009), pembelajaran merupakan suatu proses perubahan tingkah laku yang diperoleh melalui pengalaman individu yang bersangkutan. Dengan adanya pelaksanaan pembelajaran yang diberikan oleh guru, artinya guru telah memberikan pengalaman belajar langsung kepada setiap siswa.

Dalam proses pembelajaran, siswa mengalami perubahan dalam hal kognitif, afektif, maupun psikomotornya. Siswa menjadi lebih termotivasi, aktif, dan terampil dalam menyelesaikan masalah yang berkaitan dengan pembelajaran sehingga pembelajaran menjadi lebih baik dan efektif. Hal tersebut sejalan dengan pendapat Srie (2011) bahwa pembelajaran efektif adalah pembelajaran dimana siswa memperoleh keterampilan-keterampilan yang spesifik, pengetahuan dan sikap serta merupakan pembelajaran yang disenangi siswa. Intinya bahwa pembelajaran dikatakan efektif apabila terjadi perubahan-perubahan pada aspek kognitif, afektif, dan psikomotor. 
SHEs: Conference Series 3 (3) (2020) 250 - 255

\section{SIMPULAN}

Berdasarkan hasil penelitian yang telah dilaksanakan selama tiga siklus, dapat disimpulkan bahwa penggunaan Metode Belajar Membaca Tanpa Mengeja (BMTM) dapat meningkatkan keterampilan membaca siswa Kelas I SD Negeri 1 Bugel tahun ajaran 2020/2021. Hal tersebut ditunjukkan dengan adanya peningkatan pembelajaran di setiap siklus, serta tercapainya semua indikator kinerja pada penelitian ini.

\section{DAFTAR PUSTAKA}

Ahuja, P. dan Ahuja, G.C. (2010). Membaca secara Efektif dan Efisien. Kiblat Buku Utama.

Asrori, M. (2009).Psikologi Pembelajaran. Bandung: CV Wacana Prima.

Kasbolah, K. (2001). Penelitian Tindakan Kelas. Malang: Universitas Negeri Malang.

Noviana, I. (2008). Metode Belajar Membaca Tanpa Mengeja. Yogyakarta: BMTM Centre.

Noviana, I. (2009). Sembilan Langkah dalam Sembilan Hari Anak Lancar Membaca Melalui Metode Beljar Membaca tanpa Mengeja. Jakarta: Gramedia.

Srie. (2011). Pembelajaran Efektif (Pembelajaran Kontekstual dan Berfikir Kritis). Diperoleh 20 November 2014 dari http://blogguru-srie.blogspot.com/2011/11/ pembelajaran-efektif-1-pembelajaran.html 